\title{
Efektivitas Investasi dan Pembiayaan Internal: Fenomena Manajer Terlalu Percaya Diri Di Pasar Modal Indonesia
}

\author{
Deni Ramdani dan Heni Hirawati \\ Jurusan Manajemen Fakultas Ekonomika Universitas Tidar Magelang \\ J1. Kapten S. Parman No. 39 Magelang, 56116, Indonesia
}

Info Artikel

Keywords:

Financing, Investment; and

Bihaviour financial.

Kata Kunci:

Investasi; Pembiayaan; dan

Perilaku keuangan;

ISSN (print): 2598-7763

ISSN (online): 2598-7771

\footnotetext{
$\triangle$ Corresponding Author:

Deni Ramdani:

Tel. /Fax. +62 856-4780-4422

E-mail:deni.ramdani@untidar.ac.id
}

\begin{abstract}
Abtract
Overconfident managers create biases that make them overvalue their company and its investments. This study takes a sample of companies that are listed in the Indonesia Stock Exchange, for the years 2013-2017. Companies that are listed on the LQ 45 index have high liquidity so that the stock is active so it doesn't interfere with the accuracy of the research being carried out. The results showed that internal funding has a significant positive relationship with company investment. This shows that the more internal financing, the greater the scale of the investment the company will make. Internal financing and overinvestment have a significant positive correlation. So that companies tend to overinvest. Internal finance has a dual role to play in investment. One side of the bias to improve investment efficiency by increasing the scale of investment and reducing the scale of investment, on the other hand it can cause excessive investment.
\end{abstract}

Citation: Ramdani, D., dan Hirawati, H. (2020). Efektivitas Investasi dan Pembiayaan Internal: Fenomena Manajer Terlalu Percaya Diri Di Pasar Modal Indonesia. AFRE Accounting and Financial Review. 3(2) 115-125

\begin{abstract}
Abstraks
Manajer terlalu percaya diri mengakibatkan bias yang membuat mereka menilai terlalu tinggi perusahaan mereka dan investasinya. Penelitian ini mengambil sampel perusahaan yang masuk dalam Bursa Efek Indonesia, untuk tahun 2013-2017. Perusahaan yang masuk daftar indeks LQ 45 berlikuidasi tinggi sehingga saham tersebut aktif jadi tidak mengganggu akurasi penelitian yang dilakukan. Hasil penelitian menunjukkan bahwa pendanaan internal secara signifikan berhubungan positif dengan investasi perusahaan. Hal ini menunjukkan bahwa semakin banyak pembiayaan internal semakin besar skala investasi yang akan dilakukan perusahaan. Pembiayaan internal dan overinvestment memiliki korelasi positif yang signifikan. Sehingga perusahaan cenderung pada investasi berlebihan. Pembiayaan internal memiliki peran ganda dalam investasi. Satu sisi bias membaik efisiensi investasi dengan meningkatkan skala investasi dan mengurangi skala investasi, di sisi lain dapat menyebabkan investasi berlebihan.
\end{abstract}

\section{JEL Classification: G30, G32}

DOI: https://doi.org/10.26905/afr.v3i2.3834

\section{PENDAHULUAN}

Investasi memainkan peranan penting dalam memastikan pengembangan berkelanjutan perusahaan di pasar persaingan dan menciptakan nilai baru bagi pemegang saham. Kebijakan investasi perusahaan ditentukan oleh beberapa faktor yakni kebijakan ekonomi makro, pasar modal, dan operasi perusahaan (Richardson, 2006). Faktor manajerial juga penting dan bertindak irra- sional, dan ini menjadi permasalahan keuangan yang tidak efisien dengan perusahaan yang struktur tata kelola buruk (Malmendier, et al. 2011).

Perilaku manajer terlalu percaya diri sebagai ciri psikologis yang sulit diukur, ketika manajer terlalu percaya diri pada kemampuan manajemen, kemampuan penilaian investasi sehingga membentuk perilaku irrasional yang artinya bahwa penilaian mereka selalu menyimpang 
secara psikologis dari sisi aktual dengan melebihlebihkan kemampuan mereka. Terlalu percaya diri sebagai fitur psikologis yang sulit diukur oleh manajemen juga mempengaruhi operasi bisnis.

Perilaku percaya diri manajerial memicu bias yang mengarahkan para manajer untuk menilai terlalu tinggi investasi pada perusahaan mereka. Pada penelitian yang sebelumnya menunjukkan kepercayaan diri yang berlebihan manajerial mengenai kebijakan perusahaan (Gervais et al. 2011, Campbell, 2014; Huang et al. 2016).

Rock (1986) perilaku terlalu percaya diri adalah perilaku irrasional yang khas dan kecendurangan manajer memamerkannya ketika membuat keputusan bisnis. Manajer terlalu percaya diri membuat keputusan investasi yang mengakibatkan over investasi (Heaton, 2002; Bates, 2005; Xin et al.,2007). Namun studi tersebut berfokus pada dampak terlalu percaya diri manajerial pada struktur modal perusahaan, pembiayaan eksternal, jatuh tempo hutang, dan keuangan perusahaan lainnya (Shefrin, 2001; Barros et al., 2007; Yu et al.,2006; Li et al., 2009).

Menurut teori klasik pecking order (Myers, 1984), perusahaan memprioritaskan sumber mereka pembiayaan atas dasar biaya, sehingga mereka lebih memilih pembiayaan internal, dan kemudian hutang, dan yang terakhir meningkatkan equitas baru. Manajer yang terlalu percaya diri yang percaya bahwa perusahaan mereka undervalue melihat pembiayaan eksternal terlalu mahal, terutama pembiayaan ekuitas. Hasilnya mereka menampilkan preferensi pecking order untuk pembiayaan internal atas utang dan utang atas ekuitas (Malmendier, et al. 2011). Dari perspektif perilaku keuangan manajer perusahaan cenderung memilih pembiayaan internal karena mereka memiliki kontrol lebih besar atas dana internal. Oleh karena itu, manajer yang terlalu percaya diri cenderung mempengaruhi efisiensi proyek investasi dengan pembiayaan internal. Jika manajer terlalu percaya diri memiliki dana internal yang cukup untuk investasi dan tidak didisiplinkan oleh pasar modal atau mekanisme tata kelola perusahaan, mreka secara sistematis menaksir terlalu tinggi pengembalian ke proyek investasi mereka. Jika mereka tidak memiliki dana internal yang cukup, namun enggan untuk menerbitkan ekuitas baru karena mereka melihat saham perusahaan undervalue oleh pasar, akibatnya mereka mengekang investasi mereka. Manajerial terlalu percaya diri dapat menjelaskan distorsi investasi perusahaan, dimana tata kelola internal yang efektif dan mekanisme pemantauan eksternal yang labil.

Penelitan ini dimotivasi oleh Malmendier, et al. (2011) dan Campbell et al. (2011), yang menunjukkan bahwa kepercayaan yang terlalu tinggi akan menghasilkan tingkat investasi perusahaan yang lebih besar. Ketika di komparasi dengan manajer yang kurang percaya diri, manajer yang terlalu percaya diri akan mempublikasikan perusahaan mereka lebih cepat, mempertahankan sebagian besar saham perusahaan, dan kurang dipengaruhi kondisi pasar saat go public. Kemudian penelitian yang dilakukan Campbell et al. (2011) juga menemukan bahwa manajer yang terlalu percaya diri berinvestasi secara berlebihan dalam menghasilkan informasi sebelum IPO untuk memperbaiki harga penawaran akhir. IPO yang didukung oleh manajer yang sangat percaya diri mendapatkan harga yang lebih rendah. Analisis multivariate yang mengontrol faktor lain yang dianggap mempengaruhi underpricing hingga 8,5 poin persentase lebih tinggi untuk perusahaan IPO dengan manajer terlalu percaya diri. Hubungan positif antara over confidence dan under-pricing tidak sejalan dengan anggapan bahwa manajer yang sangat percaya diri secara efektif berinvestasi secara berlebihan dalam produksi informasi sebelum IPO mereka untuk mengurangi asimetri informasi dan manajer yang terlalu percaya diri waktu penawaran ekuitas mereka bertepatan dengan periode ketidaksepakatan rendah dengan investor. Dengan kasus ini, kami mengharapkan harga lebih rendah untuk manajer yang sangat percaya diri, disbanding dengan rekan mereka yang kurang percaya diri.

Penelitian yang dilakukan oleh $\mathrm{He}$ et al., (2019) menemukan hubungan positif antara manajerial terlalu percaya diri dengan melakukan pembiayaan internal pada perusahaan di Cina. Manajer yang terlalu percaya diri. Cenderung mengendalikan ilusi teknologi yang mereka miliki dan keakuratan penilaian mereka. Mereka percaya bahwa perusahaan mereka akan menunjukkan keuntungan dan memiliki potensi yang besar dan bahwa investor luar meremehkan nilai aktual perusahaan. Karena informasi asimetris dan biaya transaksi, manajer cenderung memilih pembiayaan internal. Kedua, penelitian yang dilakukan Jiang et al. (2009) perusahaan milik Negara di Cina pemegang saham terbesar di Cina pejabat pemerintah yang bertindak sebagai agen pemerintah, system ini dimana manajer perusahaan milik Negara ditunjuk oleh pemerintah. Ini adalah teknik non pasar, yang dapat menyebabkan perilaku opportunistic oleh manajer, yang 
memiliki risiko lebih tinggi untuk mengejar kepentingan pribadi mereka, ketika industri suatu proyek tersebut dalam posisi yang panas maka manajer yang terlalu percaya diri ingin membuktikan kompetensi mereka dalam menemukan peluang investasi cenderung untuk memperluas skala investasi tanpa mempertimbangkan pengembalian dan factor lain, dan mereka lebih mungkin secara membabi buta mengikuti perilaku investasi perusahaan lain yang berlebihan. Ketiga, penelitian yang dilakukan zhang et al. (2010) manajer yang terlalu percaya diri lebih mungkin di perusahaan swasta di perusahaan milik Negara menggunakan pembiayaan internal untuk mengurangi kekurangan investasi. Perusahaan bertanggung jawab memperkuat infrastruktur, memperluas permintaan domestik, dan mempromosikan pertumbuhan PDB lokal. Ketika menghadapi kendala keuangan, pemerintah akan membantu. Sebaliknya perusahaan swasta menghadapi kendala pendanaan yang lebih besar, mereka memilih lebih sedikit peluang untuk bantuan pemerintah, sehingga mereka cenderung membuat keputusan investasi konservatif untuk memenuhi kebutuhan investasi mereka manajer harus mengurangi deviden perusahaan dan meningkatkan laba ditahan dan kemampuan pendanaan internal. Manajer memiliki kesadaran risiko yang kuat. Mereka cenderung mengurangi investasi, dan meningkatkan efisiensi investasi.

Literatur keuangan meletakkan dasar teori dan penelitian empiris tentang irasionalitas diantara manajer dan dampaknya terhadap keuangan perusahaan. Misalnya, perilaku irasional seperti terlalu percaya diri diterapkan dari psikologi kognitif untuk investasi perusahaan dan pengambilan keputusan keuangan. Studi menunjukkan perilaku manajer karena mereka sendiri memiliki karakteristik dan bias kognitif, yang mencerminkan probabilitas melebih-lebihkan kemampuan seseorang untuk menyelesaikan tugas untuk meremehkan peluang. Bias ini mempengaruhi keputusan keuangan dan investasi perusahaan. Literatur sebelunya berasumsi bahwa manajer perusahaan sepenuhnya rasional, menganalisis hubungan antara keputusan investasi dan pendanaan karena pasar tidak sempurna yang disebabkan oleh konflik dalam agensi dan asimetris informasi. Namun, dalam proses pengambilan keputusan yang nyata, manajer sering menunjukkan pola irasional, seperti optimisme berlebihan dan terlalu percaya diri yang memiliki signifikansi berdampak pada pembiayaan perusahaan dan strategi investasi. Studi sebelumnya difokuskan pada tiga aspek efek manajerial yang terlalu percaya diri pada keputusan pembiayaan perusahaan, 1. Kepercayaan diri yang berlebihan manajer dan opsi pendanaan. Optimisme manajer mempengaruhi keputusan mereka tentang pembiayaan eksternal. Penelitian yang dilakukan Frank dan Goyal (2003) menemukan bahwa manajer dapat secara optimis melebih-lebihkan pengembalian proyek dan masa depan cenderung mengarah ke investasi berlebihan, dan sebagai akibatnya mereka tidak selalu sejalan dengan teori packing order, artinya pembiayaan internal digunakan terlebih dahulu setelah habis, kemudian hutang dikeluarkan sehingga tidak lagi masuk akal untuk mengeluarkan lebih banyak hutang, ekuitas dikeluarkan.

\section{PENGEMBANGAN HIPOTESIS}

Manajer yang terlalu percaya diri menginvestasikan lebih banyak sumber daya untuk mengurangi asimetri informasi sebelum di publikasikan sebagai upaya untuk menetapkan harga penawaran yang lebih efisien. Penelitian yang dilakukan Gervais et al., (2011) manajer yang terlalu percaya diri mengerahkan upaya untuk memperoleh informasi tentang kualitas investasi potensial, misalnya manajer yang terlalu percaya diri investasi berlebihan dalam produksi informasi IPO, kita harus mengamati hubungan yang dapat diprediksi antara kepercayaan berlebihan manajerial, revisi harga penawaran, dan IPO dengan harga rendah.

\section{Kepercayaan berlebihan dan modal internal}

Sebagian besar peneliti menyadari pentingnya bias kepercayaan yang berlebihan dalam operasi bisnis. Penelitian yang dilakukan Graham dan Harvey (2001) menunjukkan bahwa sebagian besar manajer percaya bahwa mereka memiliki kemampuan untuk mengendalikan keputusan pendanaan dan mempengaruhi kinerja bisnis. Karakter manajer berkaitan dengan fluktuasi harga saham perusahaan. Manajer lebih memilih pembiayaan internal karena memiliki biaya modal paling rendah dan membatasi fluktuasi dari pinjaman eksternal pasar saham.

Manajer yang terlalu percaya diri memiliki pertimbangan ketika mereka membuat keputusan mereka akan menunjukkan keuntungan dan potensi besar ketika investor luar meremehkan nilai sebenarnya. Ketika jatuh tempo untuk asimetris informasi dan biaya transaksi, manajer cenderung memilih pembiayaan internal posisi di kas. Pene- 
litian yang dilakukan oleh Deshmukh et al (2013) juga menunjukkan bahwa manajer yang terlalu percaya diri berkaitan dengan rasio pembayaran deviden yang rendah, jadi manajer yang terlalu percaya diri cenderung untuk tidak membayar deviden karena lebih memilih pembiayaan internal dengan mengurangi deviden. Oleh karena itu dibentuk hipotesis sebagai berikut:

$\mathrm{H}_{1}$ : Manajer terlalu percaya diri dan pembiayaan internal berkorelasi positf.

\section{Pembiayaan internal dan efisiensi investasi}

Meningkatkan investasi telah menjadi perhatian publik didunia industri dan akademisi. Penelitian ini kami menguji efisiensi investasi perusahaan yaitu skala investasi dan investasi non efisiensi. Evaluasi proyek investasi ditentukan oleh NPV. Jika sebuah perusahaan berinvetasi dalam proyek dengan NPV negatif, akan dianggap investasi berlebihan; jika meninggalkan proyek dengan NPV positif akan dianggap investasi yang kurang. Overinvestment atau underinvestment diklasifikasikan sebagai investasi tidak efisien. Pengalaman dilapangan, emiten sering berhadapan dengan isu perluasan skala investasi dan non efisiensi investasi (overinvestment dan underinvestment).

Teori pecking order yang dikemukakan oleh Myers (1984) menunjukkan bahwa pembiayaan internal menurunkan asimetri informasi, menghidari risiko seleksi yang merugikan dari pembiayaan eksternal, mengurangi koflik diantara pemangku kepentingan perusahaan. Ketika sebuah pembiayaan internal tersedia dalam perusahaan, perusahaan dapat memanfaatkan kelebiha dana internal untuk investasi. Namun arus kas yang berlebihan juga menyebabkan terjadinya overinvestment, sejalan dengan arus kas bebas teori investasi berlebih. Ketika manajer sebagai agen (perusahaan) yang memeiliki uang tunai, manajer memiliki kepentingan pribadi dengan memeperluas skala investasi dengan menggunakan dana yang ada. Posisi tersebut memungkinkan para manajer meningkatkan pendapatan, status, dan kekuasaan mereka untuk membangun "kerajaan bisnis".

Penelitian yang dilakukan oleh Ronneboog et al (2007) mengemukakan bahwa terdapat dua jenis kesalahan dalam perusahaan. Pertama adalah berinvestasi berlebihan saat arus kas mencukupi. Kedua kurangnya investasi dengan ekurangan arus kas. Pembiayaan internal meningkatkan terjadinya kesalahan tipe 1 tetapi mengurangi kesalahan tipe 2. Penurunan pembiayaan internal mengakibatkan kekurangan arus kas bebas, sehingga arus kas tidak dapat memenuhi kebutuhan investasi perusahaan. Jika ada investasi peluang atau proyek dengan NPV positif, perusahaan akan melakukan investasi yang tidak mencukupi. Oleh karena itu terbentuk hipotesis sebagai berikut:

$\mathrm{H}_{2 a}$ : Pembiayaan internal dan skala investasi bisnis berkorelasi positif.

$\mathrm{H}_{2 b}$ : Pembiayaan internal berkorelasi positif dengan investasi berlebih.

$\mathrm{H}_{2 c}$ : Pembiayaan internal berkorelasi negatif dengan kurangnya investasi.

Manajer terlalu percaya diri, pembiayaan internal, dan efisiensi investasi

Ketika manajer terlalu percaya diri, mereka memiliki sikap optimis terhadap prospek perusahaan kemudian adanya peningkatan investasi menjadi kabar baik dengan menngkatkan pembiayaan internal untuk meningkatkan kulaitas kinerja perusahaan. Ketika manajer terlalu percaya diri ketika harga saham dinilai rendah dipasar mereka akan cenderung memprediksi keberhasilan mereka sehingga mereka lebih mudah melakukan investasi menggunakan arus kas yang dihasilkan oleh pembiayaan internal dan mengurangi investasi yang disebabkan kekurangan arus kas. Jadi pembiayaan internal memainkan transmisi antara manajer yang terlalu percaya diri dan efisiensi investasi, meingkatnya pembiayaan internal dapat meringankan kekurangan investasi tetapi dapat juga menyebabkan investasi yang berlebihan. maka hipotesis sebagai berikut:

$\mathrm{H}_{3}$ : Manajer yang terlalu percaya diri cenderung memperluas skala investasi dengan meningkatkan pembiayaan internal

\section{DATA DAN METODE}

Data yang digunakan dalam penelitian ini diambil dari Bursa Efek Indonesia perdagangan di bursa saham tahun 2013-2017. Pemilihan sampel hanya terbatas pada emiten yang sahamnya termasuk dalam kategori saham aktif diperdagangkan. Hal ini dilakukan karena BEJ merupakan thin market yang ditandai dengan banyaknya saham tidur (Hartono, 2001 \& 2005). Oleh karena itu sampel penelitian ini perusahaan yang masuk dalam daftar indeks LQ 45, untuk tahun 2013-2017. Perusahaan yang masuk daftar indeks LQ 45 berlikuidasi tinggi sehingga saham tersebut aktif jadi tidak mengganggu akurasi penelitian 
yang dilakukan. Variable manajer overconfidence Bias psikologis dalam manajer sulit diukur secara langsung. Upaya telah dilakukan untuk menggunakan keputusan dan tindakan manajer sebagai proksi untuk kepercayaan diri mereka. Misalnya, diyakini bahwa seorang manajer yang terlalu percaya diri akan melakukan lebih banyak merger dan akuisisi, mengeluarkan lebih banyak utang, melebih-lebihkan laba masa depan perusahaan, menunda eksekusi opsi saham, dan membeli lebih banyak saham saham perusahaan mereka (Huang, 2013; Ahmed, 2013). Richardson (2006), yang membagi total investasi perusahaan menjadi investasi yang diharapkan dan investasi yang tidak diharapkan. Determinan investasi termasuk ukuran peluang pertumbuhan, leverage, usia perusahaan, ukuran perusahaan, saldo kas, industri-tetap efek, dan efek tetap tahunan. Investasi yang tidak diharapkan diukur dengan residual antara total investasi dan investasi yang diharapkan. Overconfidence manajerial tidak hanya mempengaruhi keputusan pembiayaan tetapi juga efisiensi investasi (Malmendier, et al. 2011). Ketika para manajer sangat percaya diri, mereka memegang sikap optimis terhadap prospek perusahaan dan melihat peningkatan dalam investasi sebagai berita baik. Oleh karena itu, mereka meningkatkan tingkat investasi dengan meningkatkan pembiayaan internal untuk meningkatkan kinerja perusahaan dan untuk memperoleh manfaat pribadi.

$\mathrm{INV}_{\mathrm{t}}=\mathrm{a}_{0}+\mathrm{a}_{1} \varphi_{\mathrm{t}-1}+\mathrm{a}_{2}$ Cash $_{\mathrm{t}-1}+\mathrm{a}_{3}$ Age $_{\mathrm{t}-1}+\mathrm{a}_{4}$ Sizet $-1_{1}+\alpha_{5} \operatorname{LeV}_{\mathrm{t}-1}+\mathrm{a}_{6}$ Return $_{\mathrm{t}-1}+\alpha_{7} \mathrm{INV}_{\mathrm{t}-1}+\Sigma(1)$

INV merupakan total pengeluaran investasi pada ahun berjalan $t$, dihitung sebagai jumlah asset tetap, konstruksi dalam proses, asset tidak berwujud, dan investasi jangka panjang semua ditingkatkan oleh total asset; Qt 1 adalah alat pertumbuhan di tahun sebelumnya, diwakili oleh tobins q; cash t-1adalah saldo kas dan investasi jangka pendek dikurangi dengan total asset yang diukur pada awal tahun, Age t-1 adalah usia perusahaan sejak terdaftar; size $\mathrm{t}-1$ adalah ukuran perusahaan, Lev $\mathrm{t}-1$ adalah leverage keuangan tahun sebelumnya, dinyatakan dengan total rasio hutang, dan return $\mathrm{t}-1$ adalah tingkat pengembalian saham untuk tahun sebelum investasi. Industri dan tahun adalah variable dummy. Penelitian yang dilakukan oleh Wen et al. (2004) membuat persamaan sebagai berikut untuk menguji interaksi atas kepercayaan manajerial yang berlebihan, pembiayaan internal dan efisiensi investasi
Intern $=\mathrm{a}_{0}+\mathrm{a}_{1} O C \Sigma$ Control $+\varepsilon(2)$

Dimana OC (over confidence) manajer terlalu percaya diri, diukur dengan bias perkiraan pendapatan. Jika manajer melebih-lebihkan pendapatan masa depan perusahaan mereka, variable dummy adalah 1, jika tidak adalah 0 .

Model 2 menguji hubungan antara kepercayaan manjerial dan pembiayaan internal, menguji hipotesis 1 bahwa manajer yang terlalu percaya diri dengan pembiayaan internal berkorelasi positif; bahwa manajer yang lebih optimis adalah tentang pendapatan masa depan (ketika pendapatan yang diharapkan adalah lebih tinggi daripada pendapatan actual) semakin mereka ingin menginvestasikan laba di tahan

INV (overINV/underINV) $=\mathrm{a}_{0}+\mathrm{a}_{1}$ Intern $+\Sigma$ Control $+\varepsilon(3)$

Model 3 menguji hipotesis $2 \mathrm{a}, 2 \mathrm{~b}$, dan 2c; hubungan antara efisiensi investasi dan pembiayaan internal tanpa factor kepercayaan manajerial. Diharapkan pembiayaan internal dan investasi bisnis berkorelasi positif dan pendanaan internal berkrelasi positif dengan overinvestment dan berkorelasi negative dengan underinvestment.

Selanjutnya kami menyelidiki hubungan antara investasi dan pembiayaan internal, dengan kepercayaan manjerial dipertimbangkan. Ini menguji hipotesis 3 yakni manajer yang teralu percaya diri cenderung memperluas skala investasi dengan meningkatkan pembiayaan internal, mengurangi kekurangan investasi tetapi juga mengarah ke investasi berlebih. Apakah masalah investasi (skala investasi, overinvestment atau underinvestment) terkait secara signifikan ke manajerial terlalu percaya diri (model 4).

$I N V$ (overINV/underINV) $=\mathrm{a}_{0}+\mathrm{a}_{1} O C+\sum$ Control + $\varepsilon(4)$

Jika manajer terlalu percaya diri dan pembiayaan internal berkorelasi positif (model 2) dan pembiayaan internal terkait dengan efisiensi investasi (model 3), manajer tidak percaya diri menyebabkan masalah investasi di luar pengaruhnya pada pembiayaan internal, jika tidak pembiayaan internal memainkan peran, membawa semua dampak kepercayaan manjerial terhadap masalah investasi dengan model (5)

$I N V\left(\right.$ overINV/underINV) $=\mathrm{a}_{0}+\mathrm{a}_{1} O C+\mathrm{a}_{2} I n t e r n+$ $\Sigma$ Control $+\varepsilon(5)$

Jika $a_{1+} a_{2}$ keduanya signifikan, pembiayaan internal bertindak sebagai perantara parsial. Jika $\mathrm{a}_{1}$ adalah tidak lagi signifikan, maka pembiayaan 
internal bertindak sebagai perantara penuh

INV (overINV/underINV) $=\mathrm{a}_{0}+\mathrm{a}_{1}$ Intern $+\mathrm{a}_{2}$

$\mathrm{OC} *$ Intern $+\Sigma$ Control $+\varepsilon(6)$

Kami menjalankan model (6) sebagai uji ketahanan menguji signifikansi istilah interaktif OC * Intern. Jika signifikan, kita dapat menyimpulkan bahwa manajer yang terlalu percaya diri me- nyebabkan masalah investasi dengan dampak yang lebih banyak pada pembiayaan internal. Jika tidak, pembiayaan internal bertindak dalam perantara sepenuhnya, membawa semua dampak kepercayaan manajerial pada masalah investasi. Operasinalisasi variable penelitian disajikan pada tabel 1.

Tabel 1. Operasionalisasi Variabel Penelitian

\begin{tabular}{|c|c|c|c|}
\hline Type & Variabel & Simbol & Definisi \\
\hline \multirow[t]{3}{*}{$\begin{array}{l}\text { Variabel } \\
\text { penden }\end{array}$} & Investment & INV & $\begin{array}{l}\text { total pengeluaran investasi, dihitung sebagai jumlah } \\
\text { asset tetap, konstruksi dalam proses, asset tidak ber- } \\
\text { wujud, investasi jangka panjang dengan skala total asset. }\end{array}$ \\
\hline & Overinvestment & OverINV & $\begin{array}{l}\text { Residu positif antara total investasi dan investasi yang } \\
\text { diharapkan }\end{array}$ \\
\hline & Underinvestment & UnderINV & $\begin{array}{l}\text { Nilai absolut dari residu negatif antara total investasi dan } \\
\text { investasi yang diharapkan. }\end{array}$ \\
\hline $\begin{array}{l}\text { Intermediate } \\
\text { variabel }\end{array}$ & Pembiayaan internal & Intern & Saldo laba atas total aset \\
\hline $\begin{array}{l}\text { Variabel Inde- } \\
\text { penden }\end{array}$ & $\begin{array}{l}\text { Manajer } \quad \text { terlalu } \\
\text { percaya diri (Mana- } \\
\text { gerial overconfi- } \\
\text { dence) }\end{array}$ & OC & $\begin{array}{l}\text { Kepercayaan berlebihan manajerial, diukur dengan bias } \\
\text { perkiraan pendapatan. Jika manajer melebih-lebihkan } \\
\text { pendapatan masa depan perusahaan mereka, variabel } \\
\text { dummy adalah } 1 \text {, jika tidak maka } 0 \text {. }\end{array}$ \\
\hline \multirow[t]{9}{*}{$\begin{array}{l}\text { Variabel } \\
\text { Kontrol }\end{array}$} & Ukuran Perusahaan & Size & $\begin{array}{l}\text { Ukuran perusahaan, diukur dengan logaritma dari total } \\
\text { asset. }\end{array}$ \\
\hline & Peluang Investasi & TobinQ & Tobin's Q \\
\hline & Lever & Lev & $\begin{array}{l}\text { Leverage keuangan, ditunjukkan dengan rasio hutang } \\
\text { total. }\end{array}$ \\
\hline & Operating ratio & $\mathrm{ROA}$ & $\begin{array}{l}\text { Pengembalian asset (ROA), sebagai rasio laba bersih } \\
\text { terhadap total aset. }\end{array}$ \\
\hline & Profitabilitas & EPS & $\begin{array}{l}\text { Earnings per share, dihitung sebagai rasio laba setelah } \\
\text { pajak atas total ekuitas. }\end{array}$ \\
\hline & Cash holding & $\mathrm{CF}$ & $\begin{array}{l}\text { Arus kas dari aktivitas operasi yang diukur dengan total } \\
\text { asset (Cash flows) }\end{array}$ \\
\hline & $\begin{array}{l}\text { Konsentrasi } \\
\text { kepemilikan }\end{array}$ & TOP10 & $\begin{array}{l}\% \text { saham dipegang oleh sepuluh pemangku kepentingan } \\
\text { teratas }\end{array}$ \\
\hline & Industri & Industri & Membagi perusahaan menjadi beberapa sektor \\
\hline & Tahun & Tahun & variabel berdasarkan tahun 2013 \\
\hline
\end{tabular}

\section{HASIL}

\section{Statistik Deskriptif}

Pengamatan perusahaan dari 2013 sampai 2017 rata-rata pembiayaan internal 1,50 untuk milik Negara dan 2,65 untuk non BUMN, menunjukkan bahwa perusahaan non BUMN lebih cederung menggunakan pembiayaan internal (Tabel 2). Leverage di perusahaan BUMN lebih tinggi daripda perusahaan swasta, konsisten dengan perusahaan Negara yang mendapatkan pembiayaan eksternal cenderung untuk meningkatkan hutang untuk membiayai investasi.

\section{Analisis regresi}

Manajer dengan keyakinan yang berlebih- an melalui pendanaan internal diharapkan memiliki hubungan positif. Koefisien kepercayaan berlebihan adalah 0,029 untuk semua perusahaan, 0,028 untuk BUMN ini mendukung hipotesis 1 bahwa manajer cenderung memilih pembiayaan internal. Informasi asimetris dan biaya transaksi manajer memilih pembiayaan internal dan tetap mendapatkan uang tunai saat mereka terlalu percaya diri dan percaya bahwa perusahaan mereka diremehkan oleh investor luar. Variable control ukuran perusahaan (size), peluang investasi (tobinsq), financial leverage (Lev), efisiensi operasi (ROA), profitabilitas (EPS), arus kas operasi (CF), konsentrasi kepemilikan (Top10), dan variable industri. Regresi menunjukkan bahwa pembiayaan internal berhubungan positif dengan ukuran perusahaan yang beroperasi efi- 
sien. Penggunaan leverage hutang berhubungan negative dengan internal pembiayaan di BUMN tetapi tidak signifikan di swasta. Perusahaan swasta sering menghadapi kendala pembiayaan yang lebih besar di pasar modal.

Tabel 2. Statistik Deskriptif Hasil Penelitian

\begin{tabular}{|c|c|c|c|c|c|c|}
\hline \multicolumn{7}{|c|}{ Panel A. Full Sample } \\
\hline \multirow[t]{2}{*}{ Variabel } & \multicolumn{2}{|c|}{ Total $(\mathrm{N}=45)$} & \multicolumn{2}{|l|}{ State-owned $(\mathrm{N}=20)$} & \multicolumn{2}{|c|}{ Non-state-owned $(\mathrm{N}=25)$} \\
\hline & Rerata & STD & Rerata & STD & Rerata & STD \\
\hline Intern & 2,676 & 12,708 & 1,601 & 7,453 & 2,758 & 13,020 \\
\hline INV & 0,425 & 0,219 & 0,433 & 0,227 & 0,424 & 0,218 \\
\hline Size & 21,723 & 1,072 & 22,042 & 1,156 & 21,698 & 1,062 \\
\hline Lev & 0,437 & 0,206 & 0,518 & 0,197 & 0,431 & 0,206 \\
\hline TobinQ & 2,555 & 2,658 & 2,083 & 2,353 & 2,591 & 2,677 \\
\hline ROA & 1,116 & 3,924 & 0,253 & 3,653 & 1,182 & 3,937 \\
\hline EPS & 0,392 & 0,532 & 0,451 & 0,636 & 0,387 & 0,523 \\
\hline CF & 0,041 & 0,088 & 0,040 & 0,076 & 0,041 & 0,089 \\
\hline TOP10 & 0,564 & 0,154 & 0,559 & 0,142 & 0,564 & 0,155 \\
\hline
\end{tabular}

\begin{tabular}{|c|c|c|c|c|c|c|c|c|c|c|c|}
\hline \multicolumn{12}{|c|}{ Panel B, Investment Inefficiency Sample } \\
\hline \multicolumn{2}{|c|}{$\begin{array}{l}\text { Overinvestment } \\
\text { (overINV) }\end{array}$} & \multicolumn{2}{|c|}{$\begin{array}{l}\text { Underinvestment } \\
\text { (underINV) }\end{array}$} & \multicolumn{2}{|c|}{$\begin{array}{l}\text { State-owned } \\
\text { OC }=1\end{array}$} & \multicolumn{2}{|l|}{$\mathrm{OC}=0$} & \multicolumn{2}{|c|}{$\begin{array}{l}\text { Non-state-owned } \\
O C=1\end{array}$} & \multicolumn{2}{|l|}{$\mathrm{OC}=0$} \\
\hline & & & & $\begin{array}{l}\text { over- } \\
\text { INV }\end{array}$ & $\begin{array}{l}\text { under- } \\
\text { INV }\end{array}$ & $\begin{array}{l}\text { over- } \\
\text { INV }\end{array}$ & $\begin{array}{l}\text { under- } \\
\text { INV }\end{array}$ & $\begin{array}{l}\text { over- } \\
\text { INV }\end{array}$ & $\begin{array}{l}\text { under- } \\
\text { INV }\end{array}$ & $\begin{array}{l}\text { over- } \\
\text { INV }\end{array}$ & $\begin{array}{l}\text { under- } \\
\text { INV }\end{array}$ \\
\hline Rerata & STD & Rerata & STD & Rerata & Rerata & Rerata & Rerata & Rerata & Rerata & Rerata & Rerata \\
\hline 1,956 & 10,183 & 2,363 & 14,432 & 0,393 & 1,594 & 1,814 & 0,783 & 2,202 & 2,338 & 1,935 & 2,516 \\
\hline 1,020 & 0,756 & $-0,815$ & 0,652 & 0,896 & $-1,066$ & 1,196 & $-0,748$ & 1,042 & $-0,807$ & 1,004 & $-0,817$ \\
\hline 21,790 & 1,110 & 21,679 & 1,043 & 22,212 & 21,776 & 22,145 & 21,887 & 21,872 & 21,656 & 21,715 & 21,669 \\
\hline 0,450 & 0,204 & 0,438 & 0,211 & 0,544 & 0,565 & 0,525 & 0,504 & 0,496 & 0,454 & 0,423 & 0,423 \\
\hline 2,283 & 2,588 & 2,727 & 2,820 & 2,023 & 1,826 & 1,836 & 2,365 & 2,488 & 2,998 & 2,247 & 2,681 \\
\hline 0,618 & 3,026 & 1,252 & 4,196 & $-1,988$ & 0,290 & 0,515 & 0,323 & 0,650 & 1,221 & 0,719 & 1,360 \\
\hline 0,369 & 0,512 & 0,402 & 0,459 & 0,109 & 0,451 & 0,533 & 0,504 & 0,213 & 0,246 & 0,428 & 0,448 \\
\hline 0,047 & 0,077 & 0,033 & 0,095 & 0,030 & 0,041 & 0,052 & 0,034 & 0,034 & 0,014 & 0,052 & 0,040 \\
\hline 0,567 & 0,159 & 0,563 & 0,153 & 0,578 & 0,570 & 0,523 & 0,571 & 0,554 & 0,533 & 0,574 & 0,573 \\
\hline
\end{tabular}

Data diambil dari Bursa Efek Indonesia 45 perusahaan dari 2013 sampai 2017, termasuk 20 milik negara dan 25 observasi non-milik negara. Hasil regresi model 3,4, dan 5 mencakup 1 (Tabel 3). Koefisien pembiayaan internal dengan skala investasi 0,107. Pendanaan internal secara signifikan berhubungan positif dengan investasi perusahaan, menunjukkan bahwa semakin banyak pembiayaan internal semakin besar skala investasi yang akan dilakukan perusahaan. 2. Koefisien pembiayaan internal dan investasi berlebihan adalah 0,164 menunjukkan bahwa pembiayaan internal dan investasi berlebihan 0,164, menunjukkan bahwa pembiayaan internal dan overinvestment memiliki korelasi positif yang signifikan pada level $1 \%$ sehingga perusahaan cenderung pada investasi berlebihan. 3. Koefisien internal pembiayaan dan investasi $-0,070$ signifikan pada level 1\%. Dengan demikian pembiayaan internal memiliki hubungan negative dengan kekurangan investasi; semakin banyak pembiayaan internal maka menurunkan investasi perusahaan, maka pembiayaan internal dapat mengurangi kekurangan investasi. Dengan demikian pembiayaan internal memiliki peran ganda dalam investasi. Satu sisi bias membaik efisiensi investasi dengan meningkatkan skala investasi dan mengurangi skala investasi, di sisi lain dapat menyebabkan investasi berlebihan.

Model 4 menguji dampak kepercayaan manajerial yang berlebihan pada efisiensi investasi. Skala investasi, terlalu banyak investasi, dan kurang investasi adalah variabel dependen. Hasilnya konsisten dengan penelitian yang dilakukan oleh Hao et al. (2005) mengemukakan bahwa manajer terlalu percaya diri perilaku secara positif dan signifikan terkait dengan skala investasi perusahaan mereka. Hasil regresi juga menunjukkan bahwa manajerial terlalu percaya diri berhuungan positif ketika terlalu banyak investasi dan secara signifikan berhubungan negative dengan kurangnya investasi. Ini berarti bahwa 
masalah investasi sangat signifikan terkait dengan manajerial yang terlalu percaya diri.

Keyakinan manajerial yang berlebihan dan pendanaan internal berkorelasi positif (model 2), pembiayaan internal terkait dengan efisiensi in- vestasi (model 3), dan manajerial terlalu percaya diri terkait dengan efisiesi investasi (model 4), model 5 menguji peran pembiayaan internal dalam proses dinamis.

Tabel 3 Manajer Terlalu Percaya Diri dan Keuangan Internal

\begin{tabular}{lllllll} 
Independent & \multicolumn{2}{c}{ Internal Financing (INV) } & All & State-owned & $\begin{array}{l}\text { Non-state- } \\
\text { Owned }\end{array}$ \\
\hline OC & All & State-owned & $\begin{array}{l}\text { Non-state- } \\
\text { owned }\end{array}$ & & & \\
Size & $0,029^{* *}$ & $0,028^{*}$ & $0,029^{* *}$ & & & \\
& $(2,047)$ & $(1,855)$ & $(2,028)$ & & $0,054^{* * *}$ \\
TobinQ & $0,057^{* * *}$ & $0,135^{*}$ & $0,052^{* * *}$ & $0,059^{* * *}$ & $0,134^{* * *}$ & $(2,983)$ \\
& $(3,211)$ & $(1,894)$ & $(2,855)$ & $(3,334)$ & $(1,891)$ & $-0,312^{* * *}$ \\
Lev & $-0,292^{* * *}$ & 0,082 & $-0,314^{* * *}$ & $-0,289^{* * *}$ & $0,226^{* * *}$ & $(-18,266)$ \\
& $(-17,592)$ & $(1,206)$ & $(-18,377)$ & $(-17,481)$ & $(3,863)$ & $-0,220^{* * *}$ \\
ROA & $-0,221^{* * *}$ & $-0,107$ & $-0,222^{* * *}$ & $-0,219^{* * *}$ & $-0,108$ & $(-13,239)$ \\
& $(-13,57)$ & $(-1,520)$ & $(-13,361)$ & $(-13,447)$ & $(-1,532)$ & $0,586^{* * *}$ \\
EPS & $0,564^{* * *}$ & $0,395^{* * *}$ & $0,587^{* * *}$ & $0,563^{* * *}$ & $0,397^{* * *}$ & $(35,545)$ \\
& $(35,617)$ & $(6,756)$ & $(35,605)$ & $(35,550)$ & $(6,857)$ & $-0,079^{* * *}$ \\
CF & $-0,076^{* * *}$ & $-0,114^{* * *}$ & $-0,075^{* * *}$ & $-0,080^{* * *}$ & $-0,111^{*}$ & $(-5,050)$ \\
& $(-4,896)$ & $(-1,794)$ & $(-4,718)$ & $(-5,234)$ & $(-1,781)$ & 0,020 \\
TOP10 & $0,026^{*}$ & 0,057 & 0,023 & $0,024^{*}$ & 0,057 & $(1,411)$ \\
& $(1,864)$ & $(0,979)$ & $(1,573)$ & $(1,710)$ & $(0,984)$ & $0,066^{* * *}$ \\
Industry & $0,028^{* *}$ & $0,124^{* *}$ & $0,024^{*}$ & $0,027^{*}$ & $0,122^{* *}$ & $(4,098)$ \\
Year & $(2,002)$ & $(2,189)$ & $(1,674)$ & $(1,907)$ & $(2,181)$ & Control \\
Adj, Rsq & Control & Control & Control & Control & Control & Control \\
\hline
\end{tabular}

Catatan: (1) "***", "**", "**", menunjukkan nilai signifikan masing-masing pada level 1\%, 5\%, 10\%; (2) Inside () menunjukkan nilai t; (3) Lihat Tabel 1 untuk variabel definisi; (4) Regresi (Model 2) menguji hubungan antara kepercayaan manajerial dan pembiayaan internal, menguji Hipotesis 1 bahwa terlalu percaya diri manajer dan pembiayaan internal berkorelasi positif: bahwa manajer lebih optimis tentang pendapatan masa depan (saat pendapatan yang diharapkan mereka lebih tinggi dari pendapatan sebenarnya), semakin mereka ingin menginvestasikan laba ditahan.

Regresi model 5 menunjukkan hal berikut: 1) Ketika pembiayaan internal terkendali, nilai $t$ manajer terlalu percaya diri menunjukkan investasi yang sedikit menurun 5,9 menjadi 5,8 koefisien kedua pembiayaan internal masih berpengaruh positif signifikan. 2.) Nilai t manajerial yang terlalu percaya diri dan investasi berlebihan menurun 2,3 ke 2,1. Model $4 \& 5$ berbeda pada level $1 \%$. Koefisien pembiayaan internal manajerial yang terlalu percaya diri tidak mempengaruhi overinvestment sebagai dampak pada pembiayaan internal

Kami juga menguji dampak pembiayaan internal pada efisiensi investasi dengan kepercayaan diri berlebihan di BUMN dan swasta. Ketika manajer tidak percaya diri $(\mathrm{OC}=0)$ pembiayaan internal tidak signifikan dalam kaitannya dengan skala investasi (INV) dan investasi di bawah (underINV) tetapi secara signifikan positif dalam kaitannya investasi berlebihan (overINV). Namun, ketika manajer terlalu percaya diri
$(\mathrm{OC}=1)$ intern adalah positif signifikan dalam kaitannya dengan INV, tetapi masih tidak signifikan dalam kaitannya dengan underINV.

Kontrol, nilai $\mathrm{T}$ overconfidence manajerial dan investasi sedikit menurun, dari 5,966 menjadi 5,855 . Koefisien keduanya pendanaan internal dan kepercayaan berlebihan manajerial masih positif secara signifikan. (2) Nilai $\mathrm{T}$ dari overconfidence manajerial dan investasi berlebih berkurang dari 2,331 menjadi 2,102. Mengikuti pendekatan Freedman dan Schatzkin (1992), kami menguji perbedaannya antara koefisien overconfidence manajerial dalam Model 4 dan Model 5. Ini berbeda secara signifikan dari 0 pada tingkat $1 \%$. Di Selain itu, koefisien dari pembiayaan internal dan overconfidence manajerial masih positif secara signifikan. Artinya itu kepercayaan berlebihan manajerial tidak mempengaruhi investasi berlebih hanya melalui dampaknya pada pembiayaan internal. (3) Nilai T absolut dari kepercayaan berlebihan manajerial dan kurangnya investasi 
menurun dari 2,086 menjadi 0,166. Koefisien dari kepercayaan berlebihan manajerial tidak terkait secara signifikan dengan underinvestment setelah faktor pembiayaan internal ditambahkan (Tabel
4). Ini menunjukkan bahwa manajer terlalu percaya diri mengurangi kekurangan investasi melalui pembiayaan internal.

Tabel 4. Manajer over confidence, pembiayaan internal dan efisiensi investasi

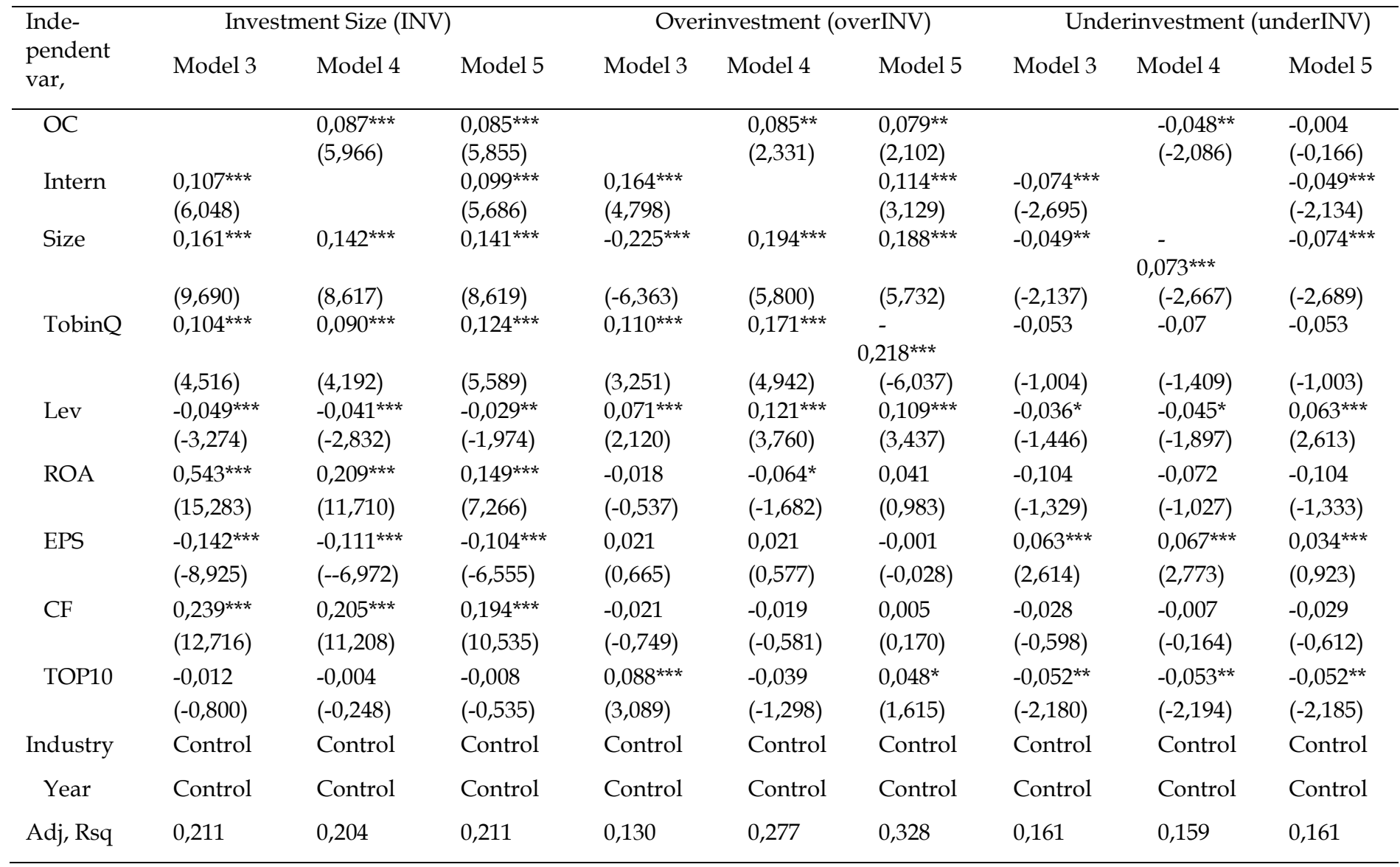

(1) "***", "**", "**", menunjukkan nilai signifikan masing-masing pada tingkat 1\%,5\%, 10\%; (2) Inside () menunjukkan nilai t; (3) Lihat Tabel 1 untuk variabel definisi; (4) Hasil regresi Model 3, 4, dan 5 ditunjukkan pada Tabel 4. Skala investasi, overinvestment, dan underinvestment variabel dependen dalam analisis. Model 3 menguji Hipotesis 2a, 2b, dan 2c: hubungan antara efisiensi investasi dan pembiayaan internal tanpa faktor kepercayaan manajerial. Model 4 menguji dampak kepercayaan berlebihan manajerial terhadap efisiensi investasi. Model 5 mempelajari caranya Dinamika antara overconfidence manajerial dan pembiayaan internal mempengaruhi inefisiensi investasi. Jika keduanya a1 (koefisien OC) dan a2 (koefisien Intern) dalam Model 5 signifikan, pembiayaan internal bertindak sebagai perantara parsial. Jika a1 tidak signifikan lagi, maka internal pembiayaan bertindak sebagai perantara penuh.

Badan Usaha Milik Negara dan Badan Usaha Milik Negara Kami juga menguji dampak pembiayaan internal terhadap efisiensi investasi dengan manajer yang terlalu percaya diri di perusahaan milik negara dan perusahaan bukan milik negara secara terpisah menggunakan Model 6. Tabel 5 menunjukkan bahwa di antara 248 pengamatan tahun perusahaan milik negara, terdapat 192 inefisiensi investasi, termasuk 89 investasi berlebih dan 103 kekurangan investasi. Ketika manajer tidak terlalu percaya diri $(\mathrm{OC}=0)$, pembiayaan internal (Intern) tidak signifikan dalam kaitannya dengan skala investasi (INV) dan un- derinvestments (underINV), tetapi secara signifikan positif dalam kaitannya dengan investasi berlebih (overINV). Namun, ketika manajer terlalu percaya diri $(\mathrm{OC}=1)$, Intern merasa terlalu percaya diri signifikan secara positif terkait dengan INV, tetapi masih tidak signifikan terkait dengan underINV. Koefisien pembiayaan internal dan overinvestments meningkat dari 0,292 menjadi 0,837 (+0,545). Kepercayaan berlebihan manajerial menyebabkan investasi yang lebih berlebihan. Di antara 3,252 observasi tahun perusahaan bukan milik negara, terdapat 2,434 inefisiensi investasi, termasuk 1,084 investasi berlebih dan 
1.350 investasi kurang. Ketika manajer tidak terlalu percaya diri $(\mathrm{OC}=0)$, Intern tidak signifikan dalam kaitannya dengan INV, underINV, dan overINV. Namun, ketika manajer terlalu percaya diri $(\mathrm{OC}=1)$, Intern tidak signifikan dalam kaitannya dengan INV dan overINV, tetapi secara signifikan negatif dalam kaitannya dengan under-
INV. Jadi, dalam sampel bukan milik negara, kepercayaan berlebihan manajerial membantu mendanai peluang bisnis dengan pembiayaan internal dan untuk mengurangi kekurangan modal

Tabel 5. Dampak Manajerial overconfidence terhadap pembiayaan internal dan efisiensi investasi bagi BUMN dan swasta.

\begin{tabular}{|c|c|c|c|c|c|c|}
\hline \multirow{2}{*}{$\begin{array}{l}\text { Independent } \\
\text { Variable }\end{array}$} & \multicolumn{2}{|c|}{ State-owned } & \multicolumn{4}{|c|}{ Non-state-owned } \\
\hline & INV & overINV & underINV & INV & overINV & underINV \\
\hline \multirow[t]{2}{*}{ Intern } & 0.089 & $0.292^{* * *}$ & -0.069 & -0.022 & 0.066 & -0.012 \\
\hline & $(0.837)$ & $(3.142)$ & $(-0.891)$ & $(-0.480)$ & $(0.814)$ & $(-0.204)$ \\
\hline \multirow[t]{2}{*}{ OC*Intern } & $0.197^{* * *}$ & $0.545^{\star * *}$ & -0.016 & 0.028 & -0.033 & -0.140 ** \\
\hline & $(2.928)$ & $(2.939)$ & $(-0.193)$ & $(-0.714)$ & $(-0.445)$ & $(-2.128)$ \\
\hline \multirow[t]{2}{*}{ Size } & $0.111^{*}$ & $0.470 * * *$ & $0.355^{* * *}$ & $0.050 * *$ & $0.088^{* * *}$ & $0.157^{* * *}$ \\
\hline & $(1.640)$ & $(4.295)$ & $(3.297)$ & $(2.283)$ & $(2.614)$ & $(4.639)$ \\
\hline \multirow[t]{2}{*}{ TobinQ } & -0.134 & $0.309 * * *$ & $0.204^{*}$ & $-0.128^{* * *}$ & $0.178^{* * *}$ & $-0.061^{*}$ \\
\hline & $(-0.798)$ & $(2.967)$ & (1.910) & $(-5.906)$ & $(5.391)$ & $(-1.784)$ \\
\hline \multirow[t]{2}{*}{ Lev } & 0.069 & $0.338^{*}$ & 0.175 & $-0.078^{* * *}$ & $0.142^{* * *}$ & $-0.207^{* * *}$ \\
\hline & $(0.426)$ & (1.892) & (1.077) & $(-3.796)$ & $(4.703)$ & $(-6.212)$ \\
\hline \multirow[t]{2}{*}{ ROA } & $-0.562^{* * *}$ & $0.332^{* * *}$ & -0.141 & $-0.064^{* *}$ & 0.018 & 0.067 \\
\hline & $(-6.157 \mathrm{v}$ & $(3.495 \mathrm{v}$ & $(-0.920)$ & $(-2.495)$ & $(0.449)$ & $(1.228)$ \\
\hline \multirow[t]{2}{*}{ EPS } & $-0.127^{* *}$ & -0.209 & $0.245^{* * *}$ & $-0.073^{* * *}$ & 0.040 & 0.009 \\
\hline & $(-2.070)$ & $(-1.249)$ & $(2.716)$ & $(-3.852)$ & (1.331) & $(0.293)$ \\
\hline \multirow[t]{2}{*}{$\mathrm{CF}$} & $0.145^{* *}$ & 0.107 & $0.156^{* * *}$ & $0.103^{* * *}$ & $-0.067^{* * *}$ & $-0.430^{* * *}$ \\
\hline & $(2.371)$ & (1.252) & $(3.359)$ & (5.987) & $(-2.595)$ & $(-14.638)$ \\
\hline \multirow[t]{2}{*}{ TOP10 } & 0.035 & -0.083 & $0.057^{* * *}$ & $-0.054^{* * *}$ & $0.071^{* * *}$ & -0.014 \\
\hline & $(0.619)$ & $(-0.913)$ & $(4.128)$ & $(-3.067)$ & $(2.698)$ & $(-0.501)$ \\
\hline Industry & Control & Control & Control & Control & Control & Control \\
\hline Year & Control & Control & Control & Control & Control & Control \\
\hline Adj. Rsq & 0.282 & 0.439 & 0.529 & 0.099 & 0.040 & 0.263 \\
\hline $\mathrm{N}$ & 248 & 89 & 103 & 3252 & 1084 & 1350 \\
\hline
\end{tabular}

Catatan: (1) "***", "**", "**", menunjukkan nilai signifikan masing-masing pada level 1\%, 5\%, 10\%; (2) Inside () menunjukkan nilai t; (3) Lihat Tabel 1 untuk variabel definisi; (4) Hasil regresi Model 6 ditunjukkan pada Tabel 5. Skala investasi, overinvestment, dan underinvestment tergantung variabel dalam analisis. Kami menjalankan Model (6) sebagai uji ketahanan yang menguji pentingnya istilah interaktif OC * Intern. Jika istilah ini signifikan, Dapat disimpulkan bahwa terlalu percaya diri manajerial menyebabkan masalah investasi lebih berdampak pada pembiayaan internal. Jika tidak, internal Pembiayaan bertindak dalam peran perantara penuh, membawa semua dampak kepercayaan manajerial pada masalah investasi. Kami memeriksa interaktif istilah dalam kasus milik negara dan bukan milik negara secara terpisah.

\section{SIMPULAN DAN SARAN}

Penelitian kami menggunakan perusahaan BUMN dan Swasta dari tahun 2013-2017 di BEI sebagai sampel untuk mengeksplorasi dampak manajerial terlalu percaya diri pada pendanaan internal dari perspektif keuangan perilaku. Bagaimana dinamika manajer yang terlalu percaya diri dan pendanaan internal mempengaruhi inefisiensi investasi (skala investasi) di BUMN dan Sawsta. Peneliti menemukan bahwa peningkatan pembiayaan internal memperluas investasi bisnis dengan demikian meningkatkan efisiensi investasi. Namun bias mengarah pada investasi ber- lebihan. Pendanaan internal adalah mediator kepercayaan manajerial dan efisiensi investasi. Manajer percaya diri cenderung meningkatkan pembiayaan internal. Karena struktur kepemilikan pemegang saham tunggal dominan. Perusahaan swasta memiliki akses yang kurang baik pada pembiayaan eksternal. Penelitian ini menunjukkan bahwa manajer cenderung menunjukkan sifat tidak rasional yang mempengaruhi keputusan investasi dan efisiensi pembiayaan. Temuan ini membantu kami memahami mekanisme pembiayaan internal dan efek manajer terlalu percaya diri. 


\section{DAFTAR PUSTAKA}

Barros, L. A. B. and Silveira, A. D. M. (2007). Overconfidence, Managerial Optimism and the Determinants of Capital Structure, SSRN Electronic Journal doi: 10.2139/ssrn. 95327

Bates, T. W. (2005). Asset Sales, Investment Opportunities, and the Use of Proceeds. Journal of Finance. 60(1), pp. 105-135.

Campbell, T. (2014). CEO optimism and the board's choice of successor. J. Corp. Financ. $29,495-510$.

Deshmukh, S., Goel, A.M., Howe, K.M. (2013). CEO overconfidence and dividend policy. J. Financ. Intermed. 22 (3), 440-463.

Frank, M. Z., and Goyal, V. K. (2003). Testing the pecking order theory of capital structure, Journal of Financial Economics 67(2). pp. 217248

Gervais, S., Heaton, H., Odean, T. (2011). Overconfidence, compensation contracts, and capital budgeting. J. Financ. 66, 1725-1777

Graham, J.R., Harvey, C.R. (2001). The theory and practice of corporate finance: evidence from the field. Nankai Bus. Rev. 60 (2-3), 187-243.

Hartono, J. M. (2001). Teori Portofolio dan Analisis Investasi Edisi 3. Jogyakarta: BPFE Jogyakarta.

Hartono, J.M. (2005). Pasar Efisien Secara Keputusan. Jakarta: PT Gramedia Pustaka Utama.

Heaton, J. B., (2002). Managerial optimism and corporate finance. Financial Management 31(2), pp. 33-45.

Huang, R., Tan, K., Faff, R. (2016). CEO overconfidence and corporate debt maturity. J. Corp. Financ. 36, 93-110

Jiang, F.X., Yin, Z.H., Su, F., Huang, L. (2009). Managerial background traits and corporate over-investment. Manage. World (1), 130-139

Li, W.L., Xie, G. L., and Hao, J.Y. (2014). The empirical study on the influence of managerial overconfidence on overinvest behavior, Journal of Shanxi Finance and Economics University (10), pp. 76-86.

Malmendier, U., Tate, G., and Yan, J. (2011). Overconfidence and Early-Life Experiences:
The Effect of Managerial Traits on Corporate Financial Policies. Journal of Finance 66(5). pp.1687 - 1733.

Myers, S. C. (1984). The Capital Structure Puzzle, Journal of Finance. 39(3), pp. 575-592.

Renneboog, L., Simons, T., Wright, M. (2007). Why do public firms go private in the UK? The impact of private equity investors, incentive realignment and undervaluation. $J$. Corp. Finance. 13 (4), 591-628.

Richardson, S. (2006). Over-investment of free cash flow, Review of Accounting Study 11, pp. 159-189

Roll, R. (1986). The Hubris Hypothesis of Corporate Takeovers. Journal of Business. 59(59), pp. 197-216.

Shefrin, H. (2001). Behavioral Corporate Finance. Journal of Applied Corporate Finance. 14(3), pp. 113-124.

Xin, Q.Q., Lin, B., and Wang, Y.C. (2007) Government Control, Executive Compensation and Capital Investment. Economic Research Journal (8), pp. 110-12

Yu, M.G., Xia, X.P., and Zou, Z.S. (2006). The Relationship between Managers' Overconfidence and Enterprises' Radical Behavior in Incurring Debts. Management World (8), pp. 104-11

Zhang, M., Wang C.F., and Jiang F.X. (2010). Is the Allocation of Credit Resources in China Efficient? Empirical Evidence from the view of Chinese Listed Companies Investment Efficiency. South China Journal of Economics. 28(7), pp. 61-71. 